\title{
The Analysis of Human Capital and Social Capital on Company Performance
}

\author{
Nurintan Asyiah Siregar ${ }^{a^{*}}$ Zuriani Ritonga $^{\mathrm{b}^{*}}$ Elvina $^{\mathrm{c}^{*}}$ \\ ${ }^{a}$ Department of Management, Sekolah Tinggi Ilmu Ekonomi, Labuhanbatu University, Sumatera Utara, Indonesia \\ E-mail: Nurintanasyiahsiregar@gmail.com \\ ${ }^{b}$ Department of Management, Sekolah Tinggi Ilmu Ekonomi, Labuhanbatu University, Sumatera Utara, Indonesia \\ E-mail: zuriani2017@gmail.com \\ ${ }^{c}$ Department of Management, Sekolah Tinggi Ilmu Ekonomi, Labuhanbatu University, Sumatera Utara, Indonesia \\ E-mail: Elvinahrp18@gmail.com
}

\begin{abstract}
Human capital is one of the main components of intellectual capital (intangible assets) owned by the company. The object of research is Bank Rakyat Indonesia (BRI) Sigambal unit. This research attempts to examine whether human capital and social capital have a significant effect on the performance of BRI Sigambal unit both individually (partially) and simultaneously. The results showed that the first, human capital had a significant effect on the performance of BRI Sigambal unit. Second, social capital had a significant effect on the performance of BRI Sigambal unit.
\end{abstract}

Keywords: Human capital, Social capital, Performance.

\section{Introduction}

In the era of globalization, the problem of human resources is in the spotlight and the foundation for companiesis expected to be able to survive. Human resources are the main role in every company activity. Although the company has the number of facilities and infrastructure and resources, without the support of human resources, the company's activities will not run well. Thus human resources are the main key that must be considered in all their needs. Human resources will determine the success of implementing company activities. At present the problem of Human Resources (HR) is a problem in determining the outcome of the development and management of the organization. The need for human resources is indispensable in facing the increasingly complex conditions of market competition. Therefore, every company must be able to adapt in the face of the development of market share in order to survive and compete.

Companies need to manage human resources professionally to maintain a balance between the demands of the company and employees. This balance is the main key for the company to be able to develop productively. Human Resource Development (HR) is a complex problem, where management is always required to make a pattern, and formulate a concept regarding the development of Human Resources (HR) in accordance with the conditions and needs of the company. Human Resource (HR) have a very vital position, dynamic and also provide its own color in a company. This is realized considering that Human Resources (HR) as a central factor in an organization. Whatever the form and purpose, the organization is made based on various visions for the benefit of humans and in its implementation the mission is managed by humans (Rachmawati, 2008: 5). The reform of the Human Resources (HR) policy aims to create reliable, capable and highly skilled human resources, aware of the role that must be played and have high performance in carrying out their duties. In fact, it is not just wages that can keep employees in a company, but many other factors can affect the level of employee performance. 
The goals and objectives of the company can be more easily achieved if the company has qualified Human Resources (HR). Increased attitude, struggle, service, work discipline, and professional ability can be done through a series of coaching and concrete actions so that efforts to improve work performance and employee loyalty can become a reality. In a company, employee performance has a very important role in empowering the entire company's HR optimally to realize the company's strategy in realizing the company's goals. Employees is one of the resources in a company that has the ability to interact with work, the physical environment, and the social environment at work so that it has a role in the industrial sector of the organization. In doing work, an employee will always look for the desired form of satisfaction, namely satisfaction in work.

Performance measurement is intended to see the effectiveness in carrying out the activities of a company or organization everyday. One of the basics of the effectiveness and efficiency of the company's business operations is a supporter of the competitiveness of companies in competing. The nature of the knowledge is still implicit and possessed by individual companies can be lost from the corporate environment because of work mutations, moving jobs to other companies that become competitors may even be death.

Because knowledge is obtained through the learning process and quite a long experience in a company by each individual incorporated in it, then if a company loses that knowledge it will be a huge loss because the investment of knowledge carried out by the company is lost. Because of that, a knowledge management needs to be implemented in every company, both business and not, so that every knowledge possessed by the company is accommodated appropriately and can be utilized later on.

An assessment of the performance of a company based on human capital is an interesting thing that should be developed in the future. Human capital is one of the main components of intellectual capital (intangible assets) owned by the company. During this assessment of the performance of companies using more tangible assets (Endri, 2011). Attention to human resources or human capital as one of the main factors of production for most companies is often compared to other production factors such as capital, technology and money. Many company leaders do not realize that the profits obtained by the company actually come from human capital, this is because the company's activities are more viewed from a business perspective. Company leaders do not see their company as a unit that contains unique knowledge and skills, or a unique set of business assets that can distinguish products or services from its competitors.

\section{Theoretical Basis}

\section{Human capital}

Human capital, can be defined as knowledge, expertise and experience of employees or managers in the company (Subramaniam \& Youndt, 2005). Human capital is represented as individual knowledge that can be in the form of: skills, experience, expertise, ideas, knowledge, competencies, capabilities and values that employees have (Eren \& Kocapinar, 2011). Basic human capital sources in creating new knowledge, learning, promoting the process of renewing skills, experimental, competency acquisition and control.

Human capital is one of the important capital for the company, because it is a source of innovation and strategy renewal, the process of re-engineering, and the source of dreams of the company (Juwita, 2007). Human Capital is an important factor in the production process because human resources are important assets in a company to improve company performance (Dahlan, 2014). This is in accordance with the research conducted by Ongkohardjo (2008) where human capital has a significant effect on company performance. A company cannot be separated from human labor, even though the company's activities have considerable capital and modern technology or advanced technology without supported by humans as resources, the company's goals will not be achieved (Mazura, 2012).

Human capital is a combination of knowledge, skills, innovation and a person's ability to carry out their duties so that they can create a value to achieve goals (Ongkorahardjo 2008). Therefore, human capital should not only be an asset, but a product that needs development from time to time, so that the output produced is also growing (Pradita 2010).

Muafi (2010) measures human capital seen from three components, namely: level of education, work experience, and competence. Whereas according to Cheng et al (2009) human resources or human capital can be measured from the level of education, work experience, professional quality, and ongoing training. Each component has a different role in creating a corporate capital that ultimately determines the value of a company. Human Capital investment is an effort to increase the added value of "goods or services" that are generated later on at the expense of the opportunity to enjoy consumption today. In accordance with the principle of human investment, economic value can develop later through a process of value added such as increasing attitudes, behavior, insight, ability, expertise and skills (Muhi, 2012). 
According to Becker (1962), human capital investment can be done by: 1) schooling, 2) training both formal and informal (on the job training), 3) health care, and 4) obtaining information about the economic system. In subsequent developments, according to Becker (1975) in Tjiptono (2011), humancapital investment can be done through: 1) education in schools, 2) training, 3) investment in company-specific knowledge, 4) choice of services, and 5) other characters related to work (wages / salaries and work hours). In his meta-analysis of studies of human capital relationships with business success, Unger, et. al. (2009) in Tjiptono (2011) identified several human capital investment indicators including: 1) education, 2) managerial experience, and 3) work experience.

\section{Social capital}

Social capital is a relationship skill between employees and managers at each level of the organization. Social capital can also be a set of relationships in social work networks within organizations. Social capital is a relationship between social institutions, values and attitudes of interaction among employees who have a contribution to economic and social development in the company. Social capital has three components, namely cognitive capital, relation capital, and structural capital. Cognitive capital includes aspects of language, ideals, and social company's past stories. Relationship is related to norms, religion, trust, the existence of present and future companies. Structural capital includes aspects of work relations between employees, network formulation and organizational adoption (Nahapiet \& Ghoshal, 1998). While Bar-al-Din OY \& Nour MY (2011) revealed that social capital has components: norms and morals, social values and beliefs, work networks in organizations.

\section{Employee performance}

Laura (2012) the main purpose of human resource management is to increase employee contributions to the company in order to achieve the productivity of the company concerned. In this case, the success of various company activities is largely determined by the performance of the employees they have. The better the level of employee performance that is owned by the company, the better the performance of the company. Mathis and Jackson (2006) define performance, basically what is done or not done by employees. Nawawi (1996) mentions performance with the term 'Karya', which is the result of the implementation of a work both physical / material and non-physical / non-material. Hasibuan (2009) argues that performance is a result of work achieved by a person in carrying out the tasks assigned to him based on skills, experience and sincerity as well as time. Rivai and Sagala (2009) state that performance is a real behavior that is displayed by everyone as work performance produced by employees in accordance with their role in the company. Employee performance is a very important thing in the company's efforts to achieve its goals. Mangkunegara (2012) defines performance as the work of quality and quantity achieved by an employee in carrying out his duties in accordance with the responsibilities given to him. Riani (2013) Performance is the level of productivity of an employee, relative to his coworkers, on some results and behaviors related to the task. Sulistiyani and Rosidah (2009) suggest that performance appraisal covers several dimensions of performance, namely: 1) quantity of work, 2) quality of work, 3) work knowledge, 4) creativity, 5) cooperation, 6) independence, 7) initiative, and 8) individual quality . Whereas according to Mitchel and Larson (1987) in Riduwan and Kuncoro (2011), arguing about aspects of performance include: 1) quality of work, 2) capability , 3) initiative, 4) communication, and 5) punctuality. Mathis and Jackson (2006) state that general employee performance includes the following elements: 1) quantity of results, 2) quality of results, 3) timeliness of results, 4) attendance, and 5) ability to work together.

\section{Methodology}

The research conducted is explanatory \& predictive. Explanatory research is a study that aims to explain the existing phenomena. Predictive is a research that tries to explain what will happen from a phenomenon (Cooper \& Schindler in Jogiyanto, 2005: 12). In this study is a population study so that the population is a research sample. The population in this study included all employees of Bank BRI unit Sigambal. The type of data used in this study is primary data, which reflects the level of perceived employees of the Bank BRI unit Sigambal: human capital, social capital and company performance. While the method of data collection is done by field surveys, namely by visiting respondents directly and distributing questionnaires to them to obtain primary data. Tools for processing data using simple regression.

\section{Discussion}

Based on the results of the validity test, it can be seen that all items whose correlation value is $>0.3$, then the item is valid. This means that all items can be used in the next process in simple regression. Besides that, it can be seen that reliable instruments are used as research instruments because of the correlation coefficient> of Cronbach's alpha coefficients.

This analysis aims to find out how much influence some independent variables have on one dependent variable. The hypothesis tested is

1. Human capital has an influence on company performance.

2. Social capital has an influence on the performance of the Company.

141 | V O L 14 
The results of data processing using simple regression as follows:

Table 1. Human Capital with Organizational performance

\begin{tabular}{llllll}
\hline $\begin{array}{l}\text { Dependent } \\
\text { variable }\end{array}$ & $\begin{array}{l}\text { Independent } \\
\text { variable }\end{array}$ & $\mathrm{B}$ & $\mathrm{t}$ & $\begin{array}{l}\text { Sig } \\
(\mathrm{p})\end{array}$ & information \\
\hline performance & $\begin{array}{l}\text { Human } \\
\text { capital }\end{array}$ & 0,765 & 7,609 & 0,000 & Proven hypothesis \\
Corelation & $\begin{array}{l}0,650 \\
0,465\end{array}$ & & & & \\
$\mathrm{R}^{2}$ & & & & \\
\hline Source: primary data processed, 2019 & & &
\end{tabular}

Based on the calculation results, the regression equation can be formulated:

$\mathrm{Y}=0.417+0.765 \mathrm{X} 1$

Based on the table above, it can be seen that sig $(\mathrm{p})$ is 0,000 smaller $0.05(0.001<0.05)$ then the hypothesis is proven. Thus the hypothesis states that there is a significant influence between human capital and performance can be accepted, so that the conclusion of human capital has an influence on performance. The amount of B is 0.765 , which means the magnitude of the influence between human capital and performance is 0.765. human capital has a positive and strong relationship with performance. This can be seen from the magnitude of the correlation coefficient ( $r$ ) of 0.650 . The magnitude of the determination coefficient 0.465 means that human capital affects performance by $46.5 \%$ and the rest is influenced by other variables not included in this study.

Table 2: Social capital with performance

\begin{tabular}{llllll}
\hline $\begin{array}{l}\text { Dependent } \\
\text { variable }\end{array}$ & $\begin{array}{l}\text { Variabel } \\
\text { bebas }\end{array}$ & $\mathrm{B}$ & $\mathrm{t}$ & $\begin{array}{l}\text { Sig } \\
(\mathrm{p})\end{array}$ & information \\
\hline performance & $\begin{array}{l}\text { Sosial } \\
\text { capital }\end{array}$ & 0,842 & 7,892 & 0,000 & Proven hypothesis \\
corelation & $\begin{array}{l}0,672 \\
\mathrm{R}^{2}\end{array}$ & & & & \\
\hline
\end{tabular}

Source: primary data processed, 2019

Based on the calculation results, the regression equation can be formulated:

$\mathrm{Y}=0.567+0.842 \mathrm{X} 2$

Based on the table above, it can be seen that sig (p) is 0,000 smaller $0.05(0.001<0.05)$ then the hypothesis is proven. Thus the hypothesis states that there is a significant influence between Social capital on performance can be accepted, so the conclusion Social capital has an influence on performance. The amount of B is 0.842 , which means that the amount of influence between Social capital and performance is 0.842 . Social capital has a positive and strong relationship with performance. This can be seen from the magnitude of the correlation coefficient (r) of 0.672 . The magnitude of the coefficient of determination 0.425 means that Social capital affects performance by $42.5 \%$ and the rest is influenced by other variables not included in this study.

\section{Conclusion and Limitations}

\section{a. Conclusion}

This study examines the effect of Human capital, and social capital on performance.

The conclusions from the results of this study are as follows:

1. Human capital has a positive influence and relationship with company performance

2. social capital has a positive influence and relationship with company performance

\section{b. Limitations}

This study has several limitations, as follows

This study only uses two independent variables, even though there are still other non-bound variables related to the company's performance. 


\section{References}

Aini, Z. (2018). Pengaruh Komitmen Afeksi, Komitmen Kontinum, Dan Komitmen Normatif Terhadap Loyalitas Pelanggan Salon Kecantikan Martha Tilaar Di Kota Banda Aceh. Jurnal Bis-A: Jurnal Bisnis Administrasi, 7(2), 47-51.

Becker, G. S., 1962, Invesment In HumanCapital : A Theoretical Analysis, The Journal of Political Economy,70 (5) : 9 - 49, October 1962.

Cheng, Yu-Shu, Yi-Pei Liu, and Chu-Yang Chien.2009.'The AssociationBetween Auditor Quality and Human Capital". Managerial AuditingJournal, Vol.24, No.6, pp.523-541

Dahlan, M.Y., Mananeke L, dan Dotulong, L.O.H.2014.Pelaksanaan Program Kesehatan Dan Keselamatan Kerja Serta Pemberian Insentif Terhadap Kinerja Karyawan Ud. Sinar Sakti Malalayang.Jurnal EMBA 1429 Vol.2 No.2 Juni 2014 , Hal. 1429-1439

Endri. (2011). Peran Human Capital Dalam Meningkatkan Kinerja Perusahaan : Suatu Tinjauan Teoritis, 6(2), $179-190$.

Juwita, S. P. (2007). PENGARUH HUMAN CAPITAL TERHADAP BUSINESS PERFORMANCE MELALUI CUSTOMER CAPITAL, 4(2), 229-250

Hasibuan, Malayu S.P. 2011. Manajemen Sumber Daya Manusia.Jakarta: Bumi Aksara

Hutajulu, S. M., \& Supriyanto, S. (2013). Tinjauan Pelaksanaan Pelatihan dan Pengembangan Karyawan pada PT. Inalum Kabupaten Batubara. Jurnal Bis-A: Jurnal Bisnis Administrasi, 2(2), 30-39.

Laura Hana.2012.Pengaruh Kompensasi Langsung dan Tidak Langsung Terhadap Kinerja Karyawan (studi kasus di ruang VIP anggrek dan ruang perawatan k, RS Pgi Cikini, jakarta).skripsi.Universitas Bakrie Jakarta

Mangkunegara, Anwar Prabu. 2012. Evaluasi Kinerja SDM. Cetakan Keenam. Penerbit Refika Aditama, Bandung

Mathis, R. L. and J. H. Jackson, 2006, Human Resource Mangement, Edisi 10,Penerbit Salemba Empat, Jakarta.

Mazura dan Mujiono. 2012. Pengaruh Insentif Terhadap Kinerja Pegawai Negeri Sipil(Studi kasus pada badan kepegawain daerah kabupaten Bengkalis). Jurnal Ilmiah Mahasiswa Vol.1 No. 1 Desember 2012

Muhi, A. H., 2012, Analisis Investasi ModalManusia Dalam PerspektifPendidikan dan Pelatihan,http//:alimuhi.staa.ipdn.ac.id,5/4/2012.

Muafi.2010.Pengaruh Strategic Human Capital TerhadapKinerja Entrepreneurial PadaOrganisasi Sektor Publik.JAMBSP Vol. 6 No. 2-Pebruari 2010: 217-229

Ongkorahardjo Martina D.P. A., Antonius Susanto, Dyna Rachmawati. 2008. "Analisis Pengaruh Human Capital Terhadap Kinerja Perusahaan (Studi Empiris pada Kantor Akuntan Publik di Indonesia)".JurnalAkuntansi dan Keuangan, Vol. 10 , No. 1.

Pradita,Rima D.2010.Hubungan Antara Kualitas Auditor Dan HumanCapital Di BadanPemeriksa Keuangan (Bpk) DanBadan Pengawasan Keuangan Dan Pembangunan(Bpkp).Skripsi.Universitas Diponegoro

Riani, Asri L. 2013. Manajemen Sumber Daya Manusia Masa Kini. Edisi Pertama. Penerbit Graha Ilmu, Yogyakarta

Riduwan dan E. A. Kuncoro, 2011, CaraMenggunakan dan Memaknai PathAnalysis (Analisis Jalur), CetakanKetiga, Penerbit Alfabeta, Bandung.

Rivai, A. F. M., M. S. M. Yasin dan B.Abdullah, 2009, ManajemenSumber Daya Manusia untukPerusahaan : Dari Teori ke Praktek,Edisi Kedua, Rajawali Pers, Jakarta.

Sulistiyani, A. T. dan Rosidah, 2009,Manajemen Sumber Daya Manusia: Konsep Teori dan Pengembangandalam Konteks Organisasi Publik,Cetakan Pertama, Graha Ilmu, Yogyakarta

Supriyanto, S., Sari, D. I., Bahgia, S., Mediyanti, S., \& Farmiati, J. (2018). Analisis Kinerja PT Perkebunan Nusantara III (Persero) Menggunakan Metode Balance Scorecard. Jurnal Bis-A: Jurnal Bisnis Administrasi, 7(2), 52-58. 